\title{
PENGARUH DUKUNGAN KELUARGA TERHADAP KEPATUHAN DIET DAN PEMBATASAN CAIRAN PASIEN GAGAL GINJAL KRONIK YANG MENJALANI HEMODIALISA DI RUMAH SAKIT PUSRI PALEMBANG TAHUN 2018
}

\author{
Leni Wijaya, Afrializa \\ Program Studi S1 Keperawatan Sekolah Tingi Ilmu Kesehatan Mitra Adiguna Palembang \\ Komplek Kenten Permai Blok J 9 - 12 Kelurahan Bukit Sangkal Palembang \\ Email: keyzhi keyzha@yahoo.com
}

\begin{abstract}
Abstrak
Gagal ginjal kronik merupakan kerusakan pada ginjal yang membuat tubuh gagal untuk mempertahankan metabolisme keseimbangan cairan dan elektrolit yang menyebabkan uremia, terapi yang dilakukan yaitu hemodialisa. Terapi tersebut membutuhkan waktu yang lama sehingga pasien membutuhkan dukungan dari keluarga serta pengawasan diet dan pembatasan cairan selama menjalankan pengobatannya agar tidak terjadi komplikasi yang dapat memperburuk keadaan pasien. Penelitian ini bertujuan untuk mengetahui pengaruh dukungan keluarga terhadap kepatuhan diet dan pembatasan cairan pasien gagal ginjal kronik yang menjalani hemodialisa di Rumah Sakit Pusri Palembang Tahun 2018. Penelitian ini dilakukan pada tanggal 1-10 Juli 2018. Jenis penelitian yang digunakan adalah Penelitian Kuantitatif dengan metode penelitian Deskriptif Analitik, melalui pendekatan Cross Sectional. Populasi penelitian ini adalah seluruh pasien gagal ginjal kronik yang menjalani hemodialisa dengan teknik Total Sampling yaitu 52 responden. Hasil analisis univariat diketahui dukungan keluarga baik sebanyak 24 responden (46,2\%) dukungan keluarga kurang baik sebanyak 28 responden (53,8\%), Kepatuhan diet kategori patuh sebanyak 22 responden (42,3\%) dan kategori tidak patuh sebanyak 30 responden (57,7\%), pembatasan cairan kategori patuh sebanyak 19 responden (36,5\%) dan tidak patuh sebanyak 33 responden 63,5\%). Hasil analisa bivariat diketahui ada pengaruh dukungan keluarga terhadap kepatuhan diet pasien gagal ginjal kronik dengan nilai $p$ value $=0,040<\alpha 0,05$, Ada pengaruh dukungan keluarga terhadap pembatasan cairan pasien gagal ginjal kronik dengan nilai $p$ value $=0,031<\alpha 0,05$. Diharapkan perawat dapat memberikan pengetahuan langsung pada pasien dan keluarga mengenai kepatuhan diet dan pembatasan cairan sehingga dapat mengurangi angka kematian.
\end{abstract}

Kata kunci : Dukungan Keluarga, Kepatuhan Diet, Pembatasan Cairan, Pasien Gagal Ginjal Kronik, Hemodialisa 


\section{PENDAHULUAN}

Ginjal merupakan salah satu organ yang memiliki fungsi penting dalam tubuh. Fungsi tersebut adalah mengatur keseimbangan asam basa serta eksresi bahan buangan kelebihan garam, mengatur konsentrasi garam dalam darah, mengatur kalsium pada tulang, membersihkan darah dan berbagai zat hasil metabolisme serta racun didalam tubuh, mempertahankan volume dan tekanan darah, mengatur produksi sel darah merah dan mengatur hormon erytopenin, renin, angiotensin dan vitamin D. Mengingat fungsi ginjal yang sangat penting maka keadaan yang dapat menimbulkan gangguan ginjal bisa menyebabkan kematian (Susatyo, 2015).

Menurut Syamsir dalam Rostanti (2016), gagal ginjal merupakan penurunan fungsi ginjal yang terjadi secara akut (kekambuhan) atau kronis (menahun). Gagal ginjal akut bila penurunan fungsi ginjal secara tiba-tiba, tetapi kemudian dapat kembali normal setelah penyebabnya segera dapat diatasi. Gagal ginjal kronik gejala yang muncul secara bertahap, biasanya tidak menimbulkan gejala awal yang jelas, sehingga penurunan fungsi ginjal tersebut sering dirasakan, tahu-tahu sudah pada tahap parah dan sulit diobati. Gejala gagal ginjal kronik atau penyakit tahap akhir adalah penyimpangan progresif, ginjal tidak dapat pulih dimana kemampuan tubuh untuk mempertahankan keseimbangan metabolik, cairan dan elektrolit mengalami kegagalan yang mengakibatkan uremi. Penyakit ginjal kronik merupakan penyakit progresif dan irreversible yaitu kemampuan tubuh gagal untuk mempertahankan metabolisme dan keseimbangan cairan dan elektrolit vang berakibat fatal menyebabkan $1 \mathrm{l}$ (Padali dalam Rostanti, 2016).

Menurut data WHO (World Health Organization) menunjukkan secara global lebih dari 500 juta orang mengalami penyakit gagal ginjal kronik (Ratnawati dalam Rostanti, 2016). Prevalensi populasi gagal ginjal kronik di Amerika Serikat atau di negara industri pada stadium 4 atau 5 sebesar $0,4 \%$. Variasi insiden dan prevalansi gagal ginjal kronik pada stadium 5 yang diberikan terapi sangat tinggi terutama dinegara industri. Prevalansi gagal ginjal kronis berdasarkan diagnosa dokter sebesar $0,2 \%$ di Indonesia, sedangkan menurut data Yayasan Peduli Ginjal (Yadugi) tahun 2008 di Indonesia terdapat 40.000 penderita gagal ginjal kronik dan terjadi peningkatan pada tahun 2010 sebesar 70.000 penderita gagal ginjal atau sebanyak 6,2\% atau 104.000 orang dari populasi penduduk Indonesia (Susatyo, 2015).

Prevalensi jumlah pasien baru di Indonesia terus meningkat dari tahun ketahun, tetapi pasien yang kemudian masih aktif pada akhir tahunnya tidak bertambah sejalan pertambahan pasien baru. Perbandingan angka kejadian pasien yang menjalani terapi hemodialisa mencapai 15.128 pasien untuk pasien baru dan 9.396 pasien untuk pasien akif pada tahun 2013, sedangkan pada tahun 2014 pasien yang menjalani terapi hemodialisa mencapai 17.193 pasien untuk pasien baru dan 11.689 pasien aktif. Provinsi Sumatera Selatan sendiri, prevalensi pasien gagal ginjal kronik yang menjalani hemodialisa 1.287 pasien untuk pasien baru dan 715 pasien untuk pasien aktif (Indonesia Renal Registry RRI dalam Eka 2017).

Berdasarkan data dari Rekam Medik Rumah Sakit Pusri Palembang (2017), angka kejadian penyakit gagal ginjal kronik yang menjalani hemodialisa mengalami peningkatan tiap tahunnya yaitu pada tahun 2015 sebanyak 628 pasien, pada tahun 2016 sebanyak 676 pasien, dan tercatat tahun 2017 pada bulan Januari sampai Oktober sebanyak 781 pasien, pada bulan November sebanyak 67 pasien gagal ginjal kronik yang menjalani hemodialisa.

Peningkatan penderita gagal ginjal kronik tersebut memerlukan berbagai penanganan medis diantaranya 
hemodialisa, dialisis peritonial atau hemofiltrasi, pembatasan cairan dan obat untuk mencegah komplikasi serius, lamanya penangan tergantung pada penyebab dan luasnya kerusakan ginjal. Salah satu tindakan medis pada penderita gagal ginjal kronik yatu dialisis dengan hemodialisa (Susatyo, 2015).

Dialisis dilakukan pada gagal ginjal untuk mengeluarkan zat-zat toksik dan limbah tubuh yang dalam keadaan normal dieksresikan oleh ginjal yang sehat. Tujuan dialisis adalah untuk membantu mempertahankan kehidupan dan kenyamanan pasien sampai fungsi ginjal pulih kembali. Prinsip dasarnya sama yaitu disfusi solid dan air dari plasma kelarutan, dialisis sebagai respon terhadap perbedaan konsentrasi tertentu, yaitu dari bagian konsentrasi paling tinggi ke konsentrasi yang paling rendah. Dalam hal ini terdapat dua teknik yang digunakan yaitu dialisis peritonial dan hemodialisa (Nursalam, 2009).

Hemodialisa merupakan proses yang digunakan pada pasien dalam keadaan sakit akut dan memerlukan terapi dialisis jangka pendek (Beberapa hari hingga minggu) atau pasien dengan penyakit ginjal stadium akhir yang memerlukan terapi jangka panjang atau bisa disebut dengan terapi seumur hidup. Tujuan hemodialisa adalah untuk mengeluarkan zat-zat nitrogen yang toksik dari dalam darah dan mengeluarkan air yang berlebihan (Suharyanto, 2013).

Cairan yang berlebihan pada pasien gagal ginjal yang menjalani hemodialisa, didalam tubuh dapat menyebabkan hipertensi, hipertropi ventrikel kiri, dan edema paru, maka pembatasan cairan harus diawasi dengan seksama karena rasa haus bukan lagi petunjuk yang dapat dipakai untuk mengetahui hidrasi tubuh. Asupan yang terlalu bebas dapat mengakibatkan beban sirkulasi menjadi berlebihan, edema, intoksikasi air sedangkan asupan yang terlalu sedikit akan mengakibatkan dehidrasi, hipotensi, dan gangguan fungsi ginjal. Selain itu diet merupakan salah satu faktor yang sangat penting dalam penatalaksanaan pasien gagal ginjal kronik yang menjalani hemodialisa. Penatalaksanaan pasien dengan gagal ginjal kronik dapat dilakukan dengan berbagai cara diantaranya kepatuhan pengaturan diet (Almatsier, 2004).

Kepatuhan adalah istilah yang dipakai untuk menjelaskan ketaatan atau pasrah pada tujuan yang telah ditentukan. Kepatuhan pada pasien gagal ginjal kronik berarti pasien harus meluangkan waktu dalam menjalani pengobatan yang dibutuhkan seperti dalam pengaturan diet dan pembatasan cairan (Potter \& Ferry dalam Magdalena, 2014).

Beberapa sumber diet yang dianjurkan harus disesuaikan dengan syarat diet penderita gagal ginjal dengan dialisis. Diet pada dialisis bergantung pada frekuensi dialisis, sisa fungsi ginjal, dan ukuran badan pasien, diet untuk pasien dengan dialisis biasanya harus direncanakan perorangan agar dipatuhi dan diterapkan selama pengobatan seperti protein tinggi untuk mempertahankan keseimbangan nitrogen pengganti asam amino yang hilang selama dialisis, karbohidrat cukup yaitu $55-75 \%$ dari kebutuhan energi total, energi cukup yaitu $35 \mathrm{kkal} / \mathrm{kg}$ BB ideal/hari, Natrium diberikan sesuai dengan jumlah urin yang keluar $/ 24$ jam, kalsium tinggi, penggunaan fosfor dibatasi, serta cairan dibatasi (Almatsier, 2004).

Pembatasan cairan seringkali sulit dilakukan oleh klien, terutama jika mereka mengkonsumsi obat-obatan yang membuat membran mukosa kering seperti deuretik, sehingga menyebabkan rasa haus dan klien berusaha untuk minum. Hal ini dikarenakan dalam kondisi normal manusia tidak dapat bertahan lebih lama tanpa asupan cairan dibandingkan dengan makanan. (Potter and Ferry dalam Permani, 2013). 
Cairan yang diminum pada pasien gagal ginjal kronik yang menjalani hemodialisa harus diawasi dengan seksama karena rasa haus bukan lagi petunjuk yang dapat dipakai untuk mengetahui hidrasi tubuh. Pembatasan cairan pada pasien gagal ginjal kronik yang menjalani hemodialisa ini sangat mendasari untuk mempertahankan bahkan meningkatkan kualitas hidup pasien, oleh sebab itu agar tidak terjadi penumpukan cairan maka jumlah cairan yang boleh dikonsumsi dalam setiap hari yaitu $500 \mathrm{ml}$ cairan ditambah jumlah urine $/ 24$ jam (Suhardjono, 2009).

Adanya pembatasan cairan ini menyebabkan pasien dengan gagal ginjal menjadi stress dan cemas dalam menghadapi penyakit yang mengancam jiwanya. Dalam keadaan seperti ini dukungan keluarga sangat dibutuhkan bagi pasien gagal ginjal kronik (Price dalam Permani, 2013).

Dukungan keluarga dapat mempengaruhi kepuasan seseorang dalam menjalani kehidupan sehari-hari termasuk kepuasan terhadap status kesehatannya terutama status kesehatan anggota keluarga yang menderita gagal ginjal kronik yang menjalani hemodialisa. Dukungan keluarga adalah upaya yang diberikan kepada orang lain, baik moril maupun materil untuk memotivasi orang tersebut dalam melaksanakan kegiatan. Bentuk dukungan yang bisa dilakukan diantaranya dukungan emosional, dukungan penilaian, dukungan instrumental dan dukungan informasi (Friedman, 2010).

Peran dan fungsi keluarga merupakan hal penting yang harus dijalankan oleh setiap anggotanya. Jika salah satu anggota keluarga terkendala atau tidak taat, organisasi keluarga akan terhambat, hal ini berakibat buruk atau tertundanya tujuan yang sudah direncanakan (Bahri, 2017).

Rina dalam Desitasari (2013) melakukan penelitian dengan judul pengaruh dukungan keluarga terhadap tingkat kecemasan pasien gagal ginjal yang menjalani hemodialisa di RSUD Arifin Achmad Pekanbaru menyimpulkan bahwa ada pengaruh yang signifikan antara dukungan keluarga dengan tingkat kecemasan berpola liner positif sempurna artinya semakin tinggi tingkat dukungan keluarga semakin rendah tingkat kecemasan pasien gagal ginjal kronik.

Berdasarkan Penelitian yang dilakukan Permani (2013), tentang pengaruh konseling pembatasan cairan oral terhadap kecemasan pasien yang menjalani hemodialisa di rawat inap RMC Rumah Sakit Telogorejo Semarang menyatakan bahwa perilaku yang dialami para responden adalah tidak mematuhi diet dan pembatasan cairan yang seharusnya dilakukan dikarenakan pasien yang menjalani hemodialisa kemungkinan mengalami keputusasaan, sehingga mereka cenderung tidak mematuhi pembatasan cairan dan terapi lainnya yang diberikan, maka komplikasi mungkin saja terjadi dan kecemasan semakin meningkat.

Hal yang sama juga dilakukan oleh Desitasari, dkk (2013) mengenai hubungan tingkat pengetahuan, sikap dan dukungan keluarga terhadap kepatuhan diet pasien gagal ginjal kronik yang menjalani hemodialisa menyatakan bahwa tidak ada hubungan antara dukungan keluarga terhadap kepatuhan diet pasien gagal ginjal yang menjalani terapi hemodialisa dengan hasil uji Chi Square di perolah nilai $p$ value $0,235>p$ value 0,05 . Hal ini dijelaskan oleh peneliti bahwa keluarga merupakan salah satu faktor yang sangat merpengaruhi ketidakpatuhan, keluarga dapat membantu menghilangkan godaan pada ketidakpatuhan dan keluarga seringkali dapat menjadi kelompok pendukung untuk memcapai kepatuhan.

\section{METODE PENELITIAN}

Dalam penelitian ini, peneliti menggunakan metode penelitian deskriptif analisis yaitu suatu bentuk penelitian yang ditujukan untuk mendeskripsikan 
fenomena-fenomena yang ada, baik fenomena alamiah maupun fenomena buatan manusia, selanjutnya dilakukan analisis distribusi frekuensi dengan menyimpulkan berdasarkan hasil rata-rata.

Rancangan penelitian yang digunakan adalah cross sectional yaitu data yang menyangkut variabel dukungan keluarga, kepatuhan diet dan pembatasan cairan pasien gagal ginjal kronik yang menjalani hemodialisa akan dikumpulkan dalam waktu yang bersama.

Populasi pada penelitian ini adalah seluruh pasien gagal ginjal kronik yang menjalani hemodialisa di Rumah Sakit Pusri Palembang tahun 2018 sebanyak 52 orang responden. Pengambilan sampel dilakukan dengan cara non probability sampling menggunakan teknik total sampling yaitu pemilihan sampel dengan menetapkan subyek yang memenuhi kriteria penelitian sehingga jumlah klien yang diperlukan terpenuhi. Sampel yang didapatkan memiliki kriteria inklusi maupun eksklusi. Adapun kriteria inklusi responden yaitu:

a. Keluarga pasien gagal ginjal kronik yang telah menjalani hemodialisa $\geq 3$ bulan.

b. Keluarga bersedia menjadi responden.

Sedangkan kriteria ekslusi dalam penelitian ini adalah:

a. Keluarga pasien gagal ginjal yang tidak menjalani hemodialisa.

b. Keluarga yang menolak atau tidak mau dijadikan sebagai sampel / responden penelitian.

Penelitian ini dilakukan di ruang hemodialisa Rumah Sakit Pusri Palembang 2018 pada tanggal 1 sampai dengan tanggal 10 Juli 2018.

Pada penelitian ini menggunakan data primer yang diperoleh melalui kuesioner yang telah dibagikan kepada pasien gagal ginjal kronik yang menjalani hemodialisa di ruang hemodialisa Rumah Sakit Pusri Palembang tahun 2018. Data primer yang dikumpulkan adalah data responden meliputi data demografi dan beberapa pertanyaan terkait dukungan keluarga dan kepatuhan diet dan pembatasan cairan pasien gagal ginjal kronik yang menjalani hemodialisa.

Untuk kuesioner dukungan keluarga terdiri dari 34 buah pernyataan yang mencakup empat jenis dukungan keluarga yaitu dukungan emosional, dukungan penilaian, dukungan Instrumental dan dukungan informasional.

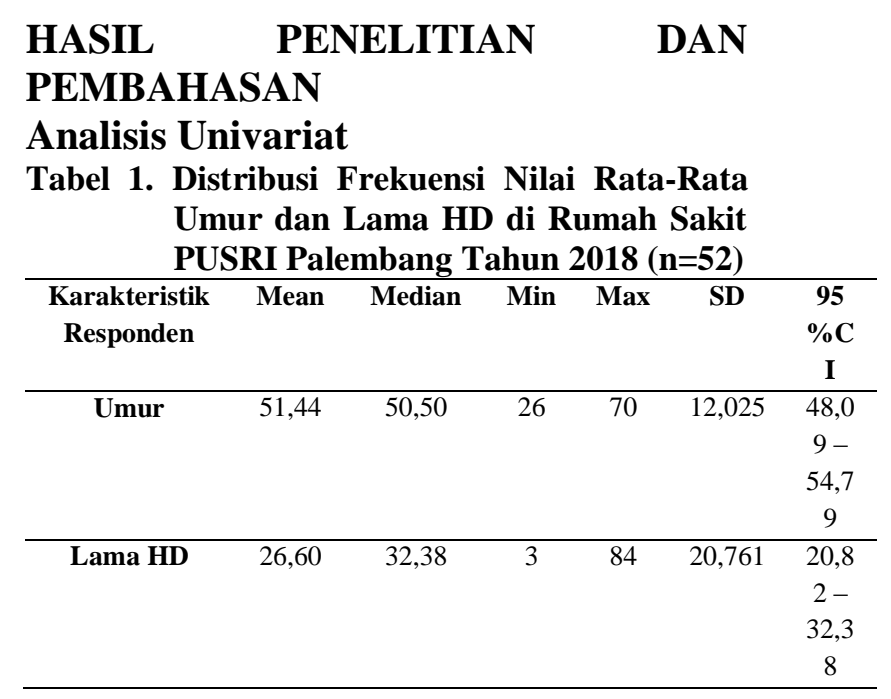

Berdasarkan tabel 1 menunjukkan bahwa nilai rata-rata umur didapatkan 51,44 tahun, Std. Deviation 12,025. Adapun umur minimum 26 tahun, umur maxsimum 70 tahun dengan tingkat kepercayaan $95 \%$ diyakini $95 \%$ umur responden dalam rentang 48,09-54,79 tahun. Sedangkan nilai rata-rata untuk lama hemodialisa didapatkan 26,60 bulan, Std. Deviation 20,761 serta lama minimum 3 bulan, lama maxsimum 84 bulan dengan tingkat kepercayaan $95 \%$ diyakini $95 \%$ lama hemodialisa responden dalam rentang 20,82-32,38 bulan.

Tabel 2.Distribusi Frekuensi Responden Berdasarkan Dukungan Keluarga di Rumah Sakit PUSRI Palembang Tahun $2018(\mathbf{n}=52)$

\begin{tabular}{ccc}
\hline Dukungan Keluarga & $\begin{array}{c}\text { Frekuen } \\
\text { si }\end{array}$ & Persentase \\
\hline Baik & 24 & $46,2 \%$ \\
\hline Kurang Baik & 28 & $53,8 \%$ \\
\hline Jumlah & $\mathbf{5 2}$ & $\mathbf{1 0 0} \%$ \\
\hline
\end{tabular}


Berdasarkan tabel 4.3 menunjukkan bahwa sebagian besar dukungan keluarga kurang baik mencapai $(53,8 \%)$.

Tabel 3.Distribusi Frekuensi Responden Berdasarkan Kepatuhan Diet di Rumah Sakit PUSRI Palembang Tahun 2018 (n=52)

\begin{tabular}{ccc}
\hline Kepatuhan & $\begin{array}{c}\text { Frekuen } \\
\text { si }\end{array}$ & Persentase \\
\hline Patuh & 22 & $42,3 \%$ \\
\hline Tidak Patuh & 30 & $57,7 \%$ \\
\hline Jumlah & $\mathbf{5 2}$ & $\mathbf{1 0 0} \%$ \\
\hline
\end{tabular}

Berdasarkan tabel 4.4 menunjukkan bahwa sebagian besar responden memiliki kepatuhan dengan kategori tidak patuh $(57,7 \%)$.

\begin{tabular}{ccc} 
Tabel & $\begin{array}{c}\text { 4.Distribusi Frekuensi } \\
\text { Berdasarkan }\end{array}$ & $\begin{array}{r}\text { Responden } \\
\text { Kepatuhan }\end{array}$ \\
$\begin{array}{l}\text { Pembatasan Cairan Di Rumah Sakit } \\
\text { PUSRI } \\
(\mathbf{n = 5 2})\end{array}$ & Palembang & Tahun 2018 \\
Thun & & \\
\hline Kepatuhan & Frekuensi & Persentase \\
\hline Patuh & 19 & $36,5 \%$ \\
\hline Tidak Patuh & 33 & $63,5 \%$ \\
\hline Jumlah & $\mathbf{5 2}$ & $\mathbf{1 0 0} \%$ \\
\hline
\end{tabular}

Berdasarkan tabel 4 menunjukkan bahwa sebagian besar responden memiliki kepatuhan dengan kategori tidak patuh $(63,5 \%)$.

\section{Analisis Bivariat}

Tabel 5. Distribusi Frekuensi Pengaruh Dukungan Keluarga Terhadap Kepatuhan Diet Pasien Gagal Ginjal Kronik Yang Menjalani Hemodialisa di Rumah Sakit PUSRI Palembang $2018(n=52)$

\begin{tabular}{|c|c|c|c|c|c|c|c|}
\hline \multirow{3}{*}{$\begin{array}{c}\text { Dukungan } \\
\text { Keluarga }\end{array}$} & \multicolumn{4}{|c|}{$\begin{array}{c}\text { Kepatuhan Diet Pasien } \\
\text { Gagal Ginjal kronik yang } \\
\text { Menjalani Hemodialisa }\end{array}$} & \multirow{2}{*}{\multicolumn{2}{|c|}{ Total }} & \multirow{3}{*}{$\begin{array}{l}\text { Nilai } P \\
(p \\
\text { Value })\end{array}$} \\
\hline & \multicolumn{2}{|c|}{ Patuh } & \multicolumn{2}{|c|}{ Tidak Patuh } & & & \\
\hline & $\mathrm{N}$ & $\%$ & $\mathrm{~N}$ & $\%$ & $\mathrm{~N}$ & $\%$ & \\
\hline Baik & 6 & $\begin{array}{c}25, \\
0\end{array}$ & 18 & $\begin{array}{c}75, \\
0\end{array}$ & 24 & $\begin{array}{c}10 \\
0\end{array}$ & \\
\hline $\begin{array}{c}\text { Kurang } \\
\text { Baik }\end{array}$ & 16 & $\begin{array}{c}57, \\
1\end{array}$ & 12 & $\begin{array}{c}42, \\
9\end{array}$ & 28 & $\begin{array}{c}10 \\
0\end{array}$ & 0,040 \\
\hline Total & 22 & $\begin{array}{c}42, \\
3\end{array}$ & 30 & $\begin{array}{c}57 \\
7\end{array}$ & 52 & $\begin{array}{c}10 \\
0 \\
\end{array}$ & \\
\hline
\end{tabular}

Berdasarkan tabel 5 menunjukkan bahwa dari 24 responden dengan kategori dukungan keluarga baik yang tidak patuh terhadap diet sebanyak 18 responden
(75,0\%) sedangkan dari 28 responden dengan kategori dukungan keluarga kurang baik yang tidak patuh terhadap diet sebanyak 12 responden (42,9\%). Dari hasil uji statistik didapatkan nilai $p$ value 0,040 yang artinya ada pengaruh dukungan keluarga terhadap kepatuhan diet pasien gagal ginjal kronik dalam menjalani hemodialisa di Ruang Hemodialisa Rumah Sakit PUSRI Palembang.

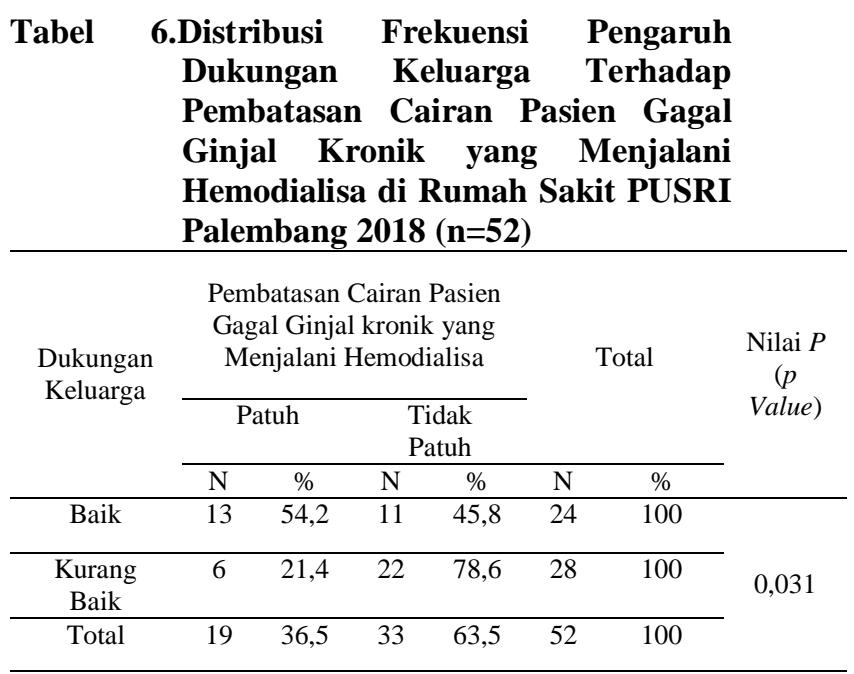

Berdasarkan tabel 6 menunjukkan bahwa dari 24 responden dengan kategori dukungan keluarga baik yang patuh terhadap pembatasan cairan sebanyak 13 responden $(54,2 \%)$ sedangkan dari 28 responden dengan kategori dukungan keluarga kurang baik yang tidak patuh terhadap pembatasan cairan sebanyak 22 responden $(78,6 \%)$. Dari hasil uji statistik didapatkan nilai $p$ value 0,031 yang artinya ada pengaruh dukungan keluarga terhadap kepatuhan dietpembatasan cairan pasien gagal ginjal kronik dalam menjalani hemodialisa di Ruang Hemodialisa Rumah Sakit PUSRI Palembang .

\section{PEMBAHASAN}

Berdasarkan hasil penelitian yang dilakukan di Rumah Sakit PUSRI Palembang pada 1-10 Juli 2018 didapatkan analisa sebagai berikut:

\section{Pengaruh Dukungan Keluarga Terhadap Kepatuhan Diet}


Berdasarkan hasil analisis univariat yang dilakukan pada 52 responden menunjukkan bahwa dari 28 responden dengan kategori dukungan keluarga kurang baik mencapai $(53,8 \%)$ dan dari 30 responden dengan kategori tidak patuh terhadap diet mencapai (57,7\%). Sedangkan untuk hasil analisis bivariat didapatkan bahwa dari 24 responden dukungan keluarga baik yang tidak patuh terhadap diet sebanyak 18 responden $(75,0 \%)$ sedangkan dari 28 responden dengan kategori dukungan keluarga kurang baik yang tidak patuh terhadap diet sebanyak 12 responden $(42,9 \%)$. Dari hasil uji statistik didapatkan nilai $p$ value 0,040 yang artinya ada pengaruh dukungan keluarga terhadap kepatuhan diet pasien gagal ginjal kronik dalam menjalani hemodialisa di Rumah Sakit PUSRI Palembang.

Menurut teori yang dikemukakan oleh Friedman (2010), dukungan keluarga dapat mempengaruhi kepuasan seseorang dalam menjalani kehidupan sehari - hari termasuk kepuasan terhadap kesehatannya. Dukungan sosial pada pasien gagal ginjal kronik yang menjalani hemodialisa terdiri dari dukungan emosional, dukungan instrumental, dukungan informasional, dukungan penilaian. Dukungan tersebut diberikan terus menerus terhadap pasien dengan harapan agar pasien patuh terhadap pengobatan yang dilakukan. Apabila dukungan ini tidak ada, maka keberhasilan pemulihan (rehabilitasi) sangat berkurang. (Biadika, 2017).

Kepatuhan pada penelitian ini ialah perilaku pasien gagal ginjal kronik dalam melaksanakan aturan diet yang sudah ditetapkan dan sesuai dengan instruksi dokter meliputi diet gagal ginjal, jenis diet, dan jumlah diet. Faktor yang mempengaruhi pasien gagal ginjal kronik dalam menjalankan diet yaitu pendidikan, faktor lingkungan, dukungan keluarga, dan perubahan model terapi. Tingkat kepatuhan adalah sikap yang ditunjukkan oleh penderita gagal ginjal kronik untuk mematuhi diet yang harus dijalani. Kepatuhan adalah suatu perubahan perilaku dari perilaku yang tidak mentaati peraturan ke perilaku yang mentaati perilaku (Notoadmodjo, 2010).

Kepatuhan sebagai ketaatan pasien dalam melaksanakan tindakan terapi. Kepatuhan pasien berarti pasien beserta keluarga harus meluangkan waktu dalam menjalankan pengobatan yang dibutuhkan termasuk dalam menjalani diet (Potter \& Perry dalam Magdalena, 2014).

Ketidakpatuhan adalah individu tidak melaksanakan sebuah program pengobatan yang disarankan, yang menyebabkan individu tidak mau untuk melaksanakan kepatuhan yang disarankan. Ketidakpatuhan dapat mendatangkan beberapa konsekuensi yang harus ditanggung oleh pasien. beberapa konsekuensi mungkin tidak dirasakan secara langsung, namun dampak serius akibat sikap tidak patuh mampu memberikan efek dikemudian waktu (Saifunurmazah dalam Biadika, 2017).

Berdasarkan penelitian yang dilakukan Eka (2017), tentang hubungan jarak dan dukungan keluarga terhadap kepatuhan pasien menjalani hemodialisa didapatkan hasil bahwa ada hubungan antara dukungan dengan kepatuhan dalam menjalani hemodialisa dengan hasil uji chi square $p$ value 0,006 . Penelitian yang sama juga dilakukan Parwanti (2015) juga menyatakan bahwa keluarga sebagai orang terdekat pasien yang selalu siap memberikan dukungan berupa informasi, perhatian, bantuan dan pujian sehingga pasien merasa tidak di asingkan. Menurut Marilyn dalam Eka (2017), terdapat hubungan yang kuat antara keluarga dan status kesehatan anggotanya dimana peran keluarga sangat penting bagi setiap aspek perawatan kesehatan anggota keluarga. Pada penelitian ini responden yang dianggap patuh yang menjalani jadwal rutin hemodialisa selama 2 kali seminggu dan tidak ada keterangan tidak hadir. Adapun pada responden yang tidak patuh 
dapat terlihat tidak adanya anggota keluarga yang menemani, ataupun karena proses hemodialisa yang terlalu lama menyebabkan responden menghentikan terapi hemodialisa dari ketentuan yang seharusnya.

Berdasarkan hasil dari observasi dan wawancara langsung yang dilakukan peneliti terhadap responden, tidak semua pasien gagal ginjal kronik yang menjalani hemodialisa didampingi oleh keluarga, sebagian pasien ada yang menggunakan kendaraan sendiri untuk menuju kerumah sakit menjalani hemodialisa dengan alasan yang beragam seperti tidak mau menyusahkan keluarga, suami, istri atau anak mereka sibuk bekerja sehingga pasien hanya diantar dan selama proses hemodialisa pasien sendirian tidak ditemani keluarga.

Pada dasarnya proses terapi tersebut dilakukan tidak cukup satu atau dua bulan saja, tetapi butuh waktu yang lama. Pasien tidak dapat melakukannya sendiri, butuh bantuan dari keluarga untuk mengantar ke rumah sakit dan melakukan kontrol ke dokter. Selain itu Dukungan keluarga, dan lingkungan yang sehat dapat membantu pasien dalam mematuhi diet serta mencegah terjadinya komplikasi yang menyebabkan kondisi pasien semakin buruk. Sedangkan, perubahan model terapi juga dapat membantu pasien untuk mematuhi diet, agar pasien tidak merasa bosan dengan model terapi yang dijalani. Pasien yang tidak mematuhi diet akan menimbulkan dampak yang serius yang dapat menyebabkan kondisi pasien semakin buruk. Oleh karena itu dukungan keluarga sangatlah penting untuk pasien yang menjalani hemodialisa.

\section{Pengaruh Dukungan Keluarga Terhadap Pembatasan Cairan}

Berdasarkan hasil analisis univariat yang dilakukan pada 52 responden menunjukkan bahwa dari 28 responden dengan kategori dukungan keluarga kurang baik mencapai $(53,8 \%)$ dan dari 33 responden dengan kategori tidak patuh terhadap pembatasan cairan mencapai $(63,5 \%)$. Sedangkan untuk hasil analisis bivariat didapatkan bahwa dari 24 responden dengan kategori dukungan keluarga baik yang patuh terhadap pembatasan cairan sebanyak 13 responden (54,2\%) sedangkan dari 28 responden dengan kategori dukungan keluarga kurang baik yang tidak patuh terhadap pembatasan cairan sebanyak 22 responden $(78,6 \%)$. Dari hasil uji statistik didapatkan nilai $p$ value $=0,031$ yang artinya ada pengaruh yang signifikan antara dukungan keluarga terhadap pembatasan cairan pasien gagal ginjal kronik yang menjalani hemodialisa di Rumah Sakit PUSRI Palembang Tahun 2018.

Menurut teori Notoadmodjo (2005) perilaku adalah suatu respon seseorang terhadap stimulus atau rangsangan dari luar subjek tersebut. Kepatuhan tersebut didukung baik oleh faktor dari dalam maupun dari luar. Faktor dari dalam meliputi pengetahuan, persepsi, dan motivasi. Sedangkan faktor dari luar meliputi lingkungan sekitar maupun non fisik. Snow dalam Biadika (2017) menyatakan bahwa derajat kepatuhan ratarata $50 \%$, derajat ketidakpatuhan rata-rata $50 \%$ dan derajat kepatuhan tersebut bertambah buruk sesuai waktu, karena semakin lama waktu yang dibutuhkan untuk memenuhi nasihat atau anjuran terapi diet dan pembatasan cairan, maka pasien akan semakin merasa bosan dan kurang mengikuti program terapi yang harus dijalaninya.

Kepatuhan sebagai realisasi perilaku, dan kepatuhan di pengaruhi oleh beberapa faktor antara lain: pengetahuan, sikap, jarak dan perilaku orang lain. Bagi penderita penyakit gagal ginjal kronik, hemodialisa akan mencegah kematian. Namun demikian, hemodialisa hilangnya aktifitas metabolik atau endokrin yang dilaksanakan oleh ginjal. kepatuhan terapi khususnya pembatasan cairan pada penderita hemodialisa merupakan hal yang 
penting untuk diperhatikan, karena jika pasien tidak patuh maka akan terjadi penumpukkan zat-zat berbahaya dan penumpukan cairan yang berlebihan dari tubuh akibat dari hasil metabolisme dalam darah yang tidak seimbang. Sehingga penderita cenderung merasa sesak napas dan merasa sakit pada seluruh tubuh, dan jika hal tersebut dibiarkan dapat menyebabkan kematian. Pasien harus menjalani dialisis sepanjang hidupnya atau sampai mendapat ginjal baru melalui operasi pencangkokan (Smeltzer, 2002).

Berdasarkan penelitian yang dilakukan Permani (2013), tentang pengaruh konseling pembatasan cairan oral terhadap kecemasan pasien yang menjalani hemodialisa di rawat inap RMC Rumah Sakit Telogorejo Semarang menyatakan bahwa perilaku yang dialami para responden adalah tidak mematuhi diet dan pembatasan cairan yang seharusnya dilakukan dikarenakan pasien yang menjalani hemodialisa kemungkinan mengalami keputusasaan, sehingga mereka cenderung tidak mematuhi pembatasan cairan dan terapi lainnya yang diberikan, maka komplikasi mungkin saja terjadi dan kecemasan semakin meningkat.

Pembatasan cairan seringkali sulit dilakukan oleh klien, terutama jika mereka mengkonsumsi obat-obatan yang membuat membran mukosa kering seperti deuretik, sehingga menyebabkan rasa haus dan klien berusaha untuk minum. Hal ini dikarenakan dalam kondisi normal manusia tidak dapat bertahan lebih lama tanpa asupan cairan dibandingkan dengan makanan. (Potter and Ferry dalam Permani, 2013).

Cairan yang diminum pada pasien gagal ginjal kronik yang menjalani hemodialisa harus diawasi dengan seksama karena rasa haus bukan lagi petunjuk yang dapat dipakai untuk mengetahui hidrasi tubuh. Pembatasan cairan pada pasien gagal ginjal kronik yang menjalani hemodialisa ini sangat mendasari untuk mempertahankan bahkan meningkatkan kualitas hidup pasien, oleh sebab itu agar tidak terjadi penumpukan cairan maka jumlah cairan yang boleh dikonsumsi dalam setiap hari yaitu 500ml cairan ditambah jumlah urine /24 jam (Suhardjono, 2009).

Adanya pembatasan cairan ini menyebabkan pasien dengan gagal ginjal menjadi stress dan cemas dalam menghadapi penyakit yang mengancam jiwanya. Dalam keadaan seperti ini dukungan keluarga sangat dibutuhkan bagi pasien gagal ginjal kronik (Price dalam Permani, 2013).

Berdasarkan hasil dari observasi dan wawancara langsung yang dilakukan peneliti terhadap responden, sebagian besar responden mengetahui aturan pembatasan cairan yang dilakukan namun karena rasa haus yang terus menerus yang responden rasakan membuat responden melanggar aturan yang diberikan sehingga cairan yang dikonsumsi lebih dari anjuran yang diberikan.

\section{KESIMPULAN}

Berdasarkan penelitian yang dilaksanakan di Rumah Sakit Pusri Palembang pada tanggal 1 sampai dengan 10 Juli 2018 dengan jumlah responden sebanyak 52 responden, maka dapat ditarik simpulan sebagai berikut:

1. Dari 52 responden penelitian dengan dukungan keluarga baik sebanyak 24 responden $(46,2 \%)$ dan responden dengan dukungan keluarga kurang baik sebanyak 28 responden $(53,8 \%)$.

2. Dari 52 responden penelitian dengan kepatuhan diet kategori patuh sebanyak 22 responden $(42,3 \%)$ dan responden dengan kepatuhan diet kategori kurang patuh sebanyak 30 responden $(57,7 \%)$.

3. Dari 52 responden penelitian dengan pembatasan cairan kategori patuh sebanyak 19 responden $(36,5 \%)$ dan responden dengan pembatasan cairan kategori kurang patuh sebanyak 33 responden $63,5 \%$ ). 
4. Ada pengaruh dukungan keluarga terhadap kepatuhan diet pasien gagal ginjal kronik dengan nilai $p$ value $=$ $0,040<\alpha 0,05$

5. Ada pengaruh dukungan keluarga terhadap pembatasan cairan pasien gagal ginjal kronik dengan nilai $p$ value $=0,031<\alpha 0,05$

\section{SARAN}

Diharapkan perawat khususnya di ruang hemodialisa dapat memberikan bimbingan konseling terkait dengan dukungan keluarga terhadap kepatuhan diet pasien gagal ginjal kronik yang menjalani hemodialisa agar dapat meningkatkan kepatuhan baik kepatuhan diet maupun pembatasan cairan, dengan cara memberikan pengetahuan langsung pada pasien dan keluarga sehingga hal tersebut dapat membantu mengurangi angka kematian.

Bagi peneliti selanjutnya diharapkan mendapatkan populasi yang lebih banyak dengan metode penelitian yang berbeda, agar dapat lebih menggali faktor-faktor terjadinya ketidakpatuhan program diet dan pembatasan cairan pasien gagal ginjal kronik yang menjalani hemodialisa, seperti perilaku dan sikap yang mempengaruhi ketidakpatuhan menjalani hemodialisa.

\section{DAFTAR PUSTAKA}

Almatsier, (2004). Penuntun diet edisi baru. Jakarta: Gramedia pustaka utama

Biadika, Rif'amik. 2017. "Hubungan pengetahuan dengan kepatuhan diet pada pasien gagal ginjal kronik di ruang hemodialisa rumah sakit islam siti khadijah palembang”. Diakses 18 November 2017 pukul 10.00 wib

Brunner \& Suddart. 2001. Buku Ajar Keperawatan Medikal Bedah (Terjemahan volume II) Jakarta : EGC.

Damayanti, Novita . 2016.Karakteristik dan dukungan keluarga dengan kepatuhan klien menjalani hemodialisa di rumah Sakit Pusri

Palembang. Diakses 18

November 2017 pukul 10.00 wib

Depkes RI, (2013). Laporan Nasional

Riskesdas 2013.

Http://litbag.depkes.go.id

(Diakses tanggal 20 November 2017)

Desitasari, 2013. "Hubungan Pengetahuan, Sikap Dan Dukungan Keluarga Terhadap Kepatuhan Diet Pasien Gagal Ginjal Kronik Yang Menjalani Hemodialisa". Universitas Riau. Diakses 18 November 2017 pukul $10.00 \mathrm{wib}$

Eka, Anggraini Mia. 2017. "Hubungan jarak dengan dukungan keluarga denan kepatuhan pasien menjalani hemodialisa di Rumah Sakit Pusri." Diakses 18 November 2017 pukul 10.00 wib

Friedman, M. M (2010). Buku Ajar Keperawatan Keluarga . Ed. 5. Jakarta : EGC

Hasdianah, dkk. 2015. "Buku Ajar Dasardasar Riset Keperawatan. Yogyakarta: Nuha Medika

H. Bakri, Maria. 2017. "Asuhan Keperawatan Keluarga". Yogyakarta: PT.Pustaka Baru

Maharani. (2015). "Repository.unisba.ac.id diakses pada tanggal 5 Mei 2018 pukul 17.55 WIB

Notoatmodjo,. (2007). Promosi Kesehatan dan Perilaku Kesehatan .Jakarta: Rineka Cipta

(2012). Metodologi 8 Penelitian Kesehatan. Jakarta: Rineka Cipta. ,. (2012). Promosi Kesehatan dan Perilaku Kesehatan .Jakarta: Rineka Cipta

Nursalam. 2008. "Konsep dan Penerapan Metodelogi Penelitian Ilmu Keperawatan Pedoman Sripsi, Tesis dan Instrumen Penelitian 
Keperawatan." Jakarta: Salemba Medika.

Nursalam. 2009. "Asuhan Keperawatan padasistem perkemihan”. Jakarta: Salemba Medika.

Nursalam. (2013). Metodologi Penelitian Ilmu Keperawatan: Pendekatan Praktis (edisi 3). Jakarta: Salemba Medika

Parwanti, Umi Febriana. (2015). Hubungan Dukungn Keluarga dengan Kualitas Hidup Pasien Hemodialisa di RS PKU Muhammadiyah Yogyakarta Unit II. $\quad 10 \quad$ Mei 2016. http://opac.say.ac.id

Permani Putri, Citra dkk. "Pengaruh Konseling: Pembatasan Cairan Oral Terhadap Kecemasan Pasien yang Menjalani Hemodialisa di Rawat Inap SMC RS Telogorejo Semarang. Diakses Diakses 18 November 2017 pukul $10.00 \mathrm{wib}$

Rostanti, Anggreini dkk. "Faktor-Faktor Yang Berhubungan Dengan Kepatuhan Menjalani Terapi Hemodialisa Pada Penyakit Ginjal Kronik Di Ruangan Dahlia Dan Melati RSUP PROF. Dr.R. D Kandou Manado. Diakses 18 November 2017 pukul 10.00 wib

Suhardjono. 2009."Booklet Edukasi Sehat dengan penyakit ginjal kronik. Jakarta: Pernefri, AsDI dan Fresenius Kabi

Suharyanto, T. \& Abdul M. (2013). Asuhan Keperawatan Pada Klien Dengan Gangguan Sistem Perkemihan. Jakarta : TIM

Susatyo, Bambang, dkk. 2015. "Gambaran Kepatuhan Diet Pasien Gagal Ginjal Kronik yang Menjalani Hemodialisa Rawat Jalan di RSUD Kayen kabupaten Pati tahun 2015. Universitas diponegoro Semarang" diakses 18 November 2017 pukul 10.00 wib www.lifestyle.kompas.com sabtu, 9 januari 2016 pukul 14.00 wib"cangkok ginjal perdana di sumateraselatan dilakukan" 